УДК 636.32.38:5765.826

(C) 2013

Ладиш І. О., кандидат сільськогосподарських наук, Бублик В. М., кандидат біологічних наук, Знагован С. Ю., кандидат медичних наук

Луганський національний аграрний університет

\title{
УЗАГАЛЬНЕННЯ РЕЗУЛЬТАТІВ ОЦІНКИ СТАНУ АДАПТАЦИЙНОЇ СИСТЕМИ ОРГАНІЗМУ ОВЕЦЬ
}

\author{
Рецензент - доктор біологічних наук О. П. Тимоченко
}

\begin{abstract}
За результатами морфологічних і біохімічних досліджень крові був розроблений клініко-біохімічний коефіцієнт, в основу якого покладено лімфоцитарно-нейтрофільний індекс. У новонароджених ярок породи прекос спостерігався більш високий коефіиієнт у порівнянні з ярками з Луганської області внаслідок більш високого рівня адаптаційних механізмів в організмі новонароджених ягнят иієї породи. Встановлено, що більш адаптованими до фізіологічних і технологічних стресів були вівиі асканійської тонкорунної породи, які розводяться в умовах Херсонської області.
\end{abstract}

Ключові слова: вівця, адаптація, організм, кров, стрес.

Постановка проблеми. В останній час інтенсифікація галузі вівчарства ставить перед виробниками низку нагальних завдань щодо підвищення показників продуктивності тварин, які безпосередньо залежать від функціонального стану, рівня протікання метаболічних процесів та захиснопристосувальних властивостей організму тварин. Слід зазначити, що вівці протягом свого життя піддаються впливу багатьох факторів зовнішнього середовища, до яких відносяться різні технологічні й фізіологічні подразники. На сьогоднішній день механізми адаптації тварин до дії техногенностресових чинників достатньо глибоко з'ясовані у скотарстві та свинарстві [2-4, 8, 11-13].

Аналіз основних досліджень і публікацій, у яких започатковано розв'язання проблеми. Як свідчить огляд робіт із даної проблеми, нині практично відсутні комплексні наукові роботи, у яких би досліджувалися морфофізіологічні механізми адаптаційних здатностей овець різних порід у випадку акліматизації, передусім в умовах регіону Донбасу $[1,6,9,10]$. Тому сьогодні актуальними стають питання подальшого вивчення механізмів адаптації та узагальнення роботи адаптаційної системи організму овець. Виконані нами дослідження $\epsilon$ сучасним науковим напрямом, що допомагає вирішити проблему відбору та розведення овець, найбільш адаптованих до різних природно-кліматичних зон України.

Мета і завдання досліджень. Метою нашої роботи була розробка критеріїв, які надали б змогу узагальнити показники стану адаптаційної системи організму овець.

Завданнями досліджень було:

1. Визначити величину клініко-біохімічного коефіцієнту (КБК) у вівцематок і новонароджених ярок асканійської тонкорунної породи та породи прекос.

2. Оцінити відносну адаптивність ярок різних порід та природно-кліматичних умов їх утримання до технологічного стресу (стриження).

Матеріали і методи досліджень. Експериментальна частина роботи була виконана в рамках договору про творчу співпрацю з НДІ тваринництва степових районів «Асканія-Нова» ім. М. Ф. Іванова, Інститутом тваринництва НААН (м. Харків) i ТОВ «Айдар» Марківського району Луганської області. Об'єктом дослідження були ярки і дорослі вівці асканійської тонкорунної (АС) і породи прекос (ПР) у різні періоди фізіологічного й технологічного навантаження (новонароджені, під час першого стриження, вагітні та після окоту, $\mathrm{n}=72$ ).

Кров для клінічного та біохімічного аналізів отримували $з$ яремної вени тварин чотирьох вікових груп, натще - у міжтравний період.

Клінічні та біохімічні показники крові визначали за загальноприйнятими методиками.

Результати досліджень. Враховуючи різноманітність показників, отриманих від тварин різних вікових груп, які утримуються у різних природно-кліматичних умовах та піддаються різним видам стресів, нами був запропонований КБК, що об'єднує морфологічні та біохімічні показники крові овець і в основу якого покладено запропонований Є. С. Кутіковим (2005) лімфоцитарно-нейтрофільний індекс, доповнений нами показниками: лужного резерву крові та білкових фракцій [7]. Розроблений нами коефіцієнт представляе собою співвідношення показника лужного резерву крові, кількості лімфоцитів та 
відсоткової частки $\gamma$-глобулінової фракції загального білка до кількості гранулоцитів та відсоткової частки $\alpha$ - і $\beta$-глобулінових фракцій загального білка.

КБК $=((Л Р \times$ лф х $\gamma$-г $):(\alpha-г$ х $\beta$-г х гр $)): 100$, де: ЛР- лужний резерв; лф - лімфоцити; $\alpha$-г - альфа-глобуліни; $\beta$-г - бета-глобуліни; $\gamma$-г гамма-глобуліни; гр - гранулоцити - сума нейтрофілів, еозинофілів, базофілів.

Показник лужного резерву відображує стан pH крові, підтримання якого є життєво необхідним. Навіть незначні зсуви реакції крові супроводжуються такими серйозними наслідками, як зміна активності ферментних систем і проникності мембран, фізико-хімічних характеристик колоїдів клітин і міжклітинних структур. Отже, нами був використаний даний біохімічний показник, за підтримку якого відповідають перш за все буферні системи крові. Рівень лімфоцитів крові до певної міри пов'язаний із вмістом $\gamma$-глобулінів, а нейтрофілів - із рівнем $\alpha$-глобулінів, як гострофазних тестів, $\beta$-глобулінів із рівнем гемоглобіну, поскільки вони беруть участь у транспорті іонів заліза [5].

У вівцематок до окоту найменший КБК відмічався у тварин породи прекос $(0,34)$, наступний за величиною показник реєструвався в маток асканійської тонкорунної породи з ТОВ «Айдар» Луганської області $(0,47)$, а найбільший - у тварин із ДПДГ «Асканія-Нова» - 0,50 (див. рис.).

У вівцематок після окоту мінімальне значення КБК відмічали у тварин асканійської тонкорунної породи з ТОВ «Айдар» Луганської області
$(0,33)$, наступним за величиною показник був у вівцематок із ДПДГ «Гонтарівка» - 0,80 і максимальним $(0,90)$ він був у вівцематок асканійської тонкорунної породи із ДПДГ «Асканія-Нова».

У новонароджених тварин найменшим КБК був в ярок асканійської тонкорунної породи $(0,15)$ із ТОВ «Айдар» Луганської області, наступний за величиною показник відмічали в ярок породи прекос $(0,20)$ ДПДГ «Гонтарівка» та найбільший - у тварин із ДПДГ «Асканія-Нова» $(2,34)$.

Проте у період першого стриження мінімальне значення КБК було в ярок породи прекос $(0,24)$, тоді як у ярок асканійської тонкорунної породи 3 ТОВ «Айдар» - 0,28; максимального значення цей показник набував у ярок із ДПДГ «АсканіяНова» $-0,95$.

Слід зазначити, що до окоту в другій половині суягності КБК в обох групах вівцематок асканійської тонкорунної породи, вирощених у різних природно-кліматичних умовах, був більшим, аніж у тварин породи прекос.

Після окоту найбільший КБК був у вівцематок асканійської тонкорунної породи, вирощених в умовах Херсонської області, що свідчить про високий рівень захисно-пристосувальних механізмів в організмі саме цих тварин у даний період.

У новонароджених ярок асканійської тонкорунної породи, отриманих від вівцематок асканійської тонкорунної породи Херсонської області, КБК був найбільшим, що зберігається у наступні періоди вирощування ягнят і зокрема на час першого стриження.

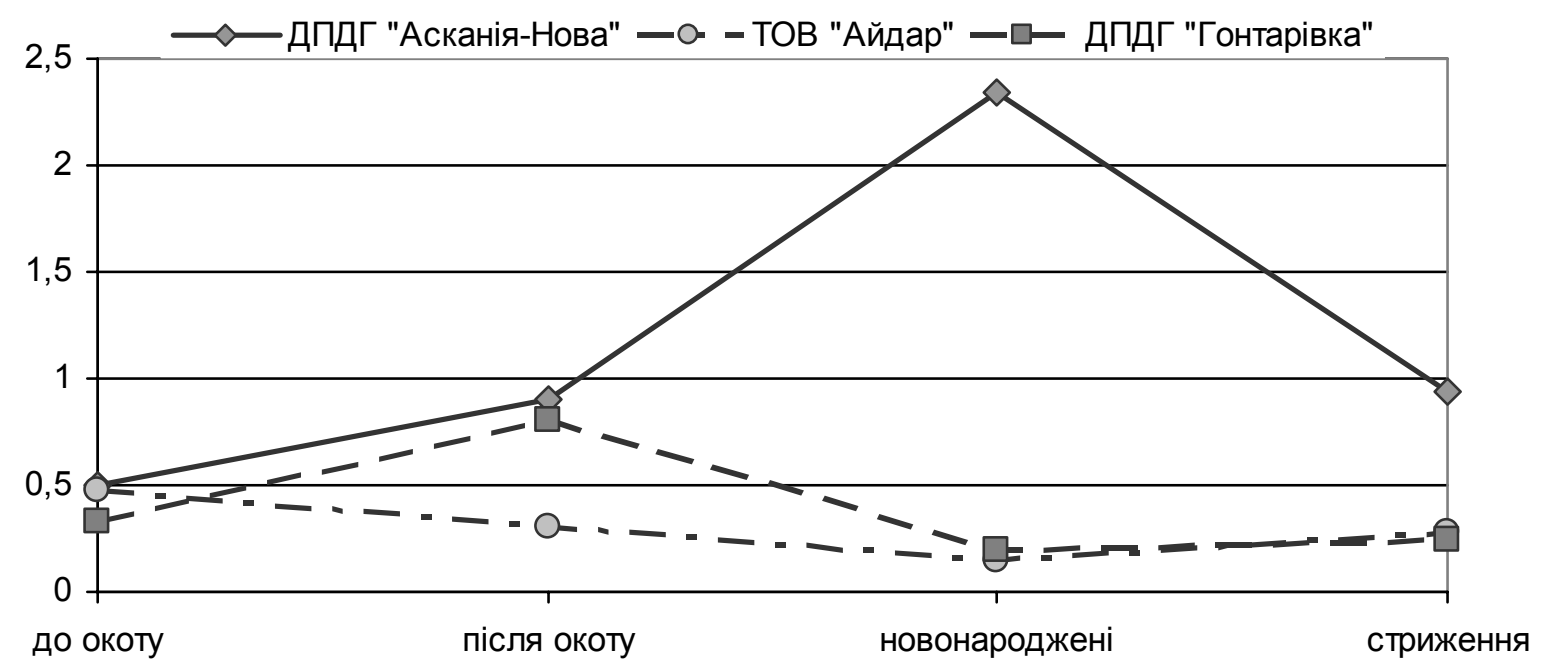

Рис. Клініко-біохімічний коефіцієнт в овець 


\section{Висновки:}

1. Встановлений максимально високий КБК у вівцематок асканійської тонкорунної породи 3 Херсонської області, який зберігається на високому рівні і в новонароджених ярок.

2. В ярок, одержаних від вівцематок асканійської тонкорунної породи з Херсонської області, на високому рівні зберігається КБК, як у порівнянні з ярками асканійської тонкорунної породи, вирощеними в умовах Луганської області, так і в порівнянні з ярками породи прекос із Харківської області.

3. Відносно низькому КБК у вівцематок асканійської тонкорунної породи з Луганської області відповідав мінімальний КБК у новонароджених ягнят порівняно 3 ягнятами, вирощеними в

\section{БІБЛІОГРАФІЯ}

1. Белогурова В. И. К вопросу оценки адаптационных способностей животных / В. И. Белогурова, И. А. Ладыш // Збірник наук. праць ЛНАУ. Луганськ, 2005.- № 47 (70). - С. 226-230.

2. Буцяк B. I. Способи попередження міграції важких металів у біологічні об'єкти / В. І. Буцяк // Наук. вісник ЛНУВМ та БТ ім. С. З. Гжицького. Львів, 2004. - Т. 6, № 3, Ч. 3. - С. 19-28.

3. Головач П. І. Фізіологічний статус і продуктивність великої рогатої худоби на різних етапах постнатального онтогенезу за впливу інсуліну : автореф. дис. ... доктора. вет. наук: спец. 03.00.13 «Фізіологія людини і тварин» / П. І. Головач. - Львів, 2004. - 40 с.

4. Карповський В. I. Типи вищої нервової діяльності великої рогатої худоби та характер адаптаційних реакцій на дію зовнішніх подразників : автореф. дис. ... доктора вет. наук.: спец. 03.00.13 «Фізіологія людини і тварин», 16.00.02 «Патологія, онкологія і морфологія тварин» / В. І. Карповський. - К., 2011. - 42 с.

5. Карташов М. I. Ветеринарна клінічна біохімія / М. І. Карташов, О. П. Тимошенко, Д. В. Кібкало [та ін.] - Х. : Еспада, 2010. - 400 с.

6. Кацุи Г. Д. Морфофизиологическая оценка животных / Г. Д. Каци. - ООО «Полиграфический центр «Максим». - Луганск, 2011. - 103 с.

7. Кутіков $C$. С. Стрес відгук організму великої рогатої худоби на проходження критичних точок онтогенезу / С. С. Кутіков, І. Л. Польщікова // Вісник аграрної науки: науково-теоретичний журнал УААН. - 2007. - № 6. - С. 39-41.

8. Мазуркевич А. Й. Щодо механізмів порушення здоров'я тварин під впливом чинників навколи- умовах Херсонської області.

4. У новонароджених ярок породи прекос спостерігався більш високий КБК у порівнянні 3 ярками з Луганської області внаслідок більш високого рівня адаптаційних механізмів в організмі новонароджених ягнят цієї породи.

5. Технологічний стрес (стриження) виявив, що найбільш адаптованими до нього були ярки асканійської тонкорунної породи 3 Херсонської області.

6. Розроблений та визначений КБК дав можливість довести, що більш адаптованими до фізіологічних і технологічних стресів були вівці асканійської тонкорунної породи, які розводяться в умовах Херсонської області.

шнього середовища та методів їх корекції / А. Й. Мазуркевич // Збірник статей Міжнародної наук.-практ. конф.: «Сучасні проблеми біології, ветеринарної медицини, зооінженерії та технології продуктів тваринництва». - Львів, 1997. C. 602-604.

9. Микитюк M. М. Селекційно-генетичні особливості адаптації та використання м'ясо-вовнових овець типа корідель в умовах північноцентрального степу України: автореф. дис. ... доктора с.-г. наук: спец. 06.02.01 «Розведення та селекція тварин» / М. М. Микитюк. - Львів, 2011. $40 \mathrm{c}$.

10. Помітун I. A. Ефективність добору ремонтних баранів за комплексом ознак / I. А. Помітун // Збірник наукових праць ЛНАУ. - Луганськ, 2010. № 100. - С. 287-289.

11. Смирнов В. С. Оценка адаптации свиноматок к интенсивному воспроизводству / В. С. Смирнов // Зоотехния. - 2003. - № 7. - С. 22-25.

12. Стояновський В. Г. Вміст деяких гормонів аденогіпофізу, щитоподібної, підшлункової і надниркових залоз у крові бичків у різні стадії фармакологічного стресу / В. Г. Стояновський, А. Д. Гуфрій // Матеріали Міжнар. конф., присвяченої пам'яті професора I. В. Шостаківської. - Львів, 2002. - C. 105.

13. Федорук P. С. Адаптація корів до умов утримання і доїння та іï корекція біологічно активними речовинами і фармакологічними препаратами: автореф. дис. ... доктора вет. наук: 03.00.13 «Фізіологія людини і тварин». - Львів. 2005.- 40 c. 